\title{
A VALIDATED HIGH PERFORMANCE LIQUID CHROMATOGRAPHY METHOD FOR DETERMINATION OF THREE BIOACTIVE COMPOUNDS, $p$-HYDROXYBENZOIC ACID, NEGUNDOSIDE AND AGNUSIDE IN VITEX SPECIES
}

\author{
Tushar Dhanani, Sonal Shah, Satyanshu Kumar* \\ Directorate of Medicinal and Aromatic Plants Research (Indian Council of Agricultural Research), \\ Boriavi, Anand 378310, Gujarat, India \\ *satyanshu66@gmail.com
}

\begin{abstract}
A validated rapid and simple isocratic high performance liquid chromatography- photo diode array (HPLC-PDA) method was developed for identification and quantification of $p$-hydroxybenzoic acid and two iridoids (negundoside and agnuside) in the extracts of two Vitex species, Vitex negundo and Vitex trifolia. The separation of the three compounds was achieved on a RP-18 $(250 \mathrm{~mm} \times 4 \mathrm{~mm}, 5 \mu \mathrm{m})$ column at $25{ }^{\circ} \mathrm{C}$ using acetonitrile $(15 \%)$ and $0.05 \%$ trifluoroacetic acid in water $(85 \%)$. The limit of detection (LOD) were 1.0, 2.5 and $2.5 \mu \mathrm{g} \mathrm{ml}^{-1}$ for $p$-hydroxybenzoic acid, negundoside and agnuside, respectively. Similarly, the limit of quantification (LOQ) were 2.5, 5.0 and $5.0 \mu \mathrm{g} \mathrm{ml}^{-1}$ for $p$-hydroxybenzoic acid, negundoside and agnuside, respectively. Good linearity $\left(r^{2}>0.999\right)$ was observed for all three compounds in a wide concentration range. Using the developed HPLC method, the three compounds were identified and quantified in leaves and bark extracts of Vitex negundo and Vitex trifolia. The novelty of the developed and validated HPLC method is that the three marker compounds in the extracts of Vitex species, $p$-hydroxybenzoic acid, negundoside and agnuside, can be simultaneously identified and quantified within a run time of 25 minute.
\end{abstract}

Keywords: $p$-hydroxybenzoic acid; iridoids; negundoside; agnuside; Vitex negundo; Vitex trifólia; method validation

\section{ВАЛИДИРАН МЕТОД СО ВИСОКОЕФИКАСНА ТЕЧНА ХРОМАТОГРАФИЈА ЗА ОПРЕДЕЛУВАЫЕ НА ТРИ БИОАКТИВНИ СОЕДИНЕНИЈА, $p$-ХИДРОКСИБЕНЗОЕВА КИСЕЛИНА, НЕГУНДОЗИД И АГНУЗИД ВО ВИДОВИ ОД VITEX}

\begin{abstract}
Разработен е брз и едноставен валидиран изократски метод со високоефиксна течна хроматографија - детектор со низа диоди (HPLC-PDA) за идентификација и квантитативно определување на $p$-хидроксибензоева киселина и два иридоиди (негундозид и агнузид) во екстракти од два вида Vitex, Vitex negundo и Vitex trifolia. Раздвојувањето на трите соедеиненија е постигнато на колона RP-18 (250 mm $\times 4 \mathrm{~mm}, 5 \mu \mathrm{m})$ на $25{ }^{\circ} \mathrm{C}$ со употреба на ацетонитрил $(15 \%)$ и $0,05 \%$ трифлуорооцетна киселина во вода (85\%). Границите на детекција (LOD) изнесуваа $1,0 \mu \mathrm{g}$ $\mathrm{ml}^{-1}, 2,5 \mu \mathrm{g} \mathrm{ml}^{-1}$ и $2,5 \mu \mathrm{g} \mathrm{ml}^{-1}$ соодветно за $p$-хидроксибензоева киселина, негундозид и агнузид. Постигната е добра линеарност $\left(r^{2}>0.999\right)$ за сите три соедененијиа во широк опсег на концентрации. Со примена на разработениот метод на HPLC, трите соединенија се идентификувани и квантитативно определни во лисја и екстракти од кора на Vitex negundo и Vitex trifolia. Новината на развиениот и валидираниот метод на HPLC е во тоа што е можно трите соединенија во екстракти од видови на Vitex истовремено да се идентификуваат и квантитативно да се определат за само 25 минути.
\end{abstract}

Клучни зборови: p-хидроксибензоева киселина; негундозид; агнузид; Vitex negundo; Vitex trifólia; валидација на метод 


\section{INTRODUCTION}

The genus Vitex belongs to the family Lamiaceae. It includes 80 genera and about 800 species. Investigations of some Vitex species have resulted in the isolation of iridoid glycosides, including: agnuside (AGN), eurostoside, negundoside (NGN), 2'-p-hydroxylbenzoylmussaenosidic acid, 6'-p-hydroxybenzoylmussaenosidic acid, nishindaside and isonishindaside from leaves; AGN and 10$O$-vanilloyaucubin from fruits; AGN, limoniside and pedunculariside from stem bark [1-10]. $V$. negundo is widely used in Indian systems of medicine for its medicinal properties and this plant has been extensively studied for its analgesic, antiinflammatory, anticonvulsant and antioxidant activities [11-14]. Flavonoids, iridoids, terpenes and steroids are the major classes of compounds isolated from $V$. negundo [15]. V. trifolia is known to possess pharmacological properties such as antipyretic and antibacterial activities and is effective against asthma and allergic diseases [16-18]. V. trifolia is known to produce a variety of diterpenoids and iridoids. Its leaves contain many bioactive phytochemicals such as flavonoids, sterols, diterpenoids and iridoids. The leaves are considered useful as an external application for rheumatic pain, sprains etc. The roots are used to treat febrifuge, painful inflammations, cough and fever, while the flowers are used in treatment of fever, and fruits in amenorrhoea [19]. Although, all parts of $V$. negundo and $V$. trifolia are used in traditional systems of medicine, the leaves are the most potent for medicinal uses. NGN (Figure 1B) and AGN (Figure 1C) are the active constituents of $V$. negundo and $V$. trifolia leaves. NGN, an iridoid $O$-glycoside isolated from $V$. negundo protected human liver cells against calcium mediated toxicity induced by carbon tetrachloride via inhibition of lipid peroxidation, followed by an improved intracellular calcium homeostasis and inhibition of $\mathrm{Ca}^{2+}$ dependent proteases [20]. AGN, another iridoid glycoside, composed of aucubin and $p$-hydroxybenzoic acid, PHBA (Figure 1A) was also reported as a chemotaxonomic marker of the genus Vitex and was isolated from $V$. negundo, $V$. cymosa and V. agnus castus [21-24]. Pandey et al. [24] reported significant antiarthritic activity of AGN associated with significant suppression of inflammatory mediators and T cell mediated cytokines (Th1/Th2). AGN also inhibits vascular permeability and leukocyte migration in vivo. Furthermore, a combination of NGN and AGN increased osteoblast differentiation and mineralization in vitro, thereby, supporting use of $V$. negundo in traditional medicine [15]. PHBA exhibits estrogenic activity in human breast cancer cell lines, as well as antioxidant activity [2526].
(A)<smiles>O=C(O)C1C=CC(O)=CC1</smiles><smiles>C[C@@]1(O)CC[C@H]2C(C(=O)O)=COC(OC3OC4[I-]C3C(OC(=O)c3ccc(O)cc3)C(O)C4O)[C@H]21</smiles><smiles>O=C(OCC1=CC(O)C2C=COC(=O)C12)c1ccc(O)cc1</smiles>

Fig. 1. Structure of PHBA (A), NGN (B) and AGN (C) [35]

For scientific and clinical acceptability of plant derived drugs, chemical profiling is essential. HPLC is the dominant separation technique used for the identification and quantification of the active principles in herbal raw materials and formulations made from them. Options to improve the sensitivity and resolution of HPLC in cases of complex isomeric mixtures in plant matrices make HPLC the preferred chromatographic assay method. Although a huge number of research publications are available in the literature regarding isolation, structural characterization and pharmacological activities of biologically active molecules from the Vitex species from India and worldwide, only a few validated HPLC methods are available in the literature for the analysis of iridoid from Vitex species. A HPLC method for the simultaneous analysis of PHBA, NGN and AGN in different plant parts of $V$. negundo and $V$. trifolia has not been 
reported. Hoberg et al. [23] reported a HPLC method for the simultaneous determination of PHBA and AGN in V. Agni-Casti Fructus with a total run time of 23 min using a gradient elution mode with acetonitrile and $O$-phosphoric acid as mobile phase. Panicker [27] reported a HPLC method for estimation of AGN, NGN and 1,4dihydroxybenzoic acid from Vitex negundo Linn. Pandey et al. [24] reported a reversed phase HPLC method for the quantification of AGN in leaf extract of V. negundo. Sing et al. [28] and Lokhande et al. [29] reported a HPLC method for the determination of negundoside in leaves of $V$. negundo. Roy et al. [30] reported a HPLC method for the simultaneous determination of NGN, AGN and three minor flavonoids in the leaves of $V$. negundo. Shah et al. [31] also reported a validated HPLC method for simultaneous identification and quantification of PHBA and AGN in two Vitex species from India. A validated ultra-performance liquid chromatography diode array detection method for the quantitative analysis of agnuside, isovitexin, casticin, 5-hydroxykaempferol-3,6,7,4'-tetramethylether and vitetrifolin in Vitex agnus castus fruits was reported by Hogner et al. [32]. In addition to HPLC methods, high performance thin layer chromatography (HPTLC) methods have also been reported for quantitative analysis of iridoid in Vitex extracts. Lokhande et al. [33] reported a HPTLC method for quantification of NGN in Vitex negundo leaves. Four markers (casticin, chrysoplenol-D, $p$-hydroxybenzoic acid and $p$ methoxybenzoic acid) were simultaneously quantified by HPTLC [34]. Tiwari et al. [35] reported a validated HPTLC method for simultaneous quantification of NGN, AGN and 6'-p-hydroxy benzoyl mussaenosidic acid in $V$. trifolia and $V$. negundo. To the best of our knowledge, a validated HPLC method for the simultaneous determination of PHBA, NGN and AGN in Vitex species has not been reported. Keeping the above points in view, the present HPLC method was developed for determination of PHBA, NGN and AGN in different extracts of $V$. negundo and $V$. trifolia.

\section{EXPERIMENTAL}

\subsection{Plant material and chemicals}

Leaves and bark of $V$. negundo and $V$. trifolia were collected from the herbal garden of the Directorate of Medicinal and Aromatic Plants Research (Boriavi, Anand, Gujarat, India) during the year 2011. Leaves and bark of $V$. negundo and $V$. trifolia were dried in the shade and a fine pow- der of dried samples was used for preparation of the extract. HPLC grade solvents methanol, acetonitrile and analytical grade trifluroacetic acid (TFA) were purchased from Merck (Mumbai, India). Deionized water used throughout the experiment was obtained from a Millipore water purification system (Millipore, gradient, $0.22-\mu \mathrm{m}$ pore size). NGN was purchased from Natural Remedies (Bangalore, India). AGN was purchased from Chromadex (USA) and PHBA was purchased from Sigma-Aldrich (Mumbai, India).

\subsection{Preparation of standard and sample solutions}

Standard stock solutions of PHBA, NGN and AGN (500.0 $\mu \mathrm{g} \mathrm{ml}^{-1}$, each) were prepared in HPLC grade methanol and working solutions of lower concentration were prepared by appropriate dilution of the stock solution. Plant samples (leaves and bark, $50 \mathrm{~g}$ each) were extracted with methanol six times at room temperature. Methanol extracts were pooled together and concentrated under reduced pressure. Thereafter, methanolic extract was suspended in water and sequentially extracted with hexane, chloroform and ethyl acetate [34-35]. Hexane extract was dried over anhydrous sodium sulfate and concentrated under reduced pressure to produce a residue of hexane extract. Similar processing of chloroform and ethyl acetate extracts provided concentrated extracts of chloroform and ethyl acetate, respectively. Remaining water fractions were also concentrated to produce an aqueous extract. Concentrated extracts were further vacuum dried to remove traces of residual solvent. Stock solutions of different extracts were prepared by dissolving extract in methanol $\left(1.0 \mu \mathrm{g} \mathrm{ml}^{-1}\right)$ and filtered through a $0.45-\mu \mathrm{m}$ membrane filter. Stock solutions of the standards and extract samples were stored at $4{ }^{\circ} \mathrm{C}$ and were brought to room temperature before use.

\subsection{Chromatographic conditions and method validation}

The HPLC system for chromatographic analysis consisted of a separation module (Waters 600E) equipped with Empower software (Waters) and quaternary pump, an inline vacuum degasser and a photodiode array detector (Waters, 2996). The chromatographic separation was carried out in an isocratic elution mode on RP-18 column (Merck, India) with $5 \mu \mathrm{m}$ particle size, $4.6 \mathrm{~mm}$ internal diameter and $250 \mathrm{~mm}$ length. The mobile phase was a mixture of solvents: acetonitrile (15.0 $\%)$ and $0.05 \%$ TFA in water $(85 \%, v / v, \mathrm{pH}=2.25)$. The solvent flow rate was $1.0 \mathrm{ml} \mathrm{min}^{-1}$ and the in- 
jection volume was $20 \mu \mathrm{l}$. Column temperature was $25^{\circ} \mathrm{C}$. The photo diode array detector wavelength was set at $258 \mathrm{~nm}$ for the determination of PHBA, NGN and AGN in different extracts of $V$. negundo and $V$. trifolia. Chromatographic peaks were identified on the basis of retention time as well as by matching their spectra with the spectra of the standards. Concentration of PHBA, NGN and AGN in extract samples were calculated by comparing the integrated peak areas of the individual compounds with that of a standard curve prepared from the corresponding standards.

\subsection{Calibration curves of PHBA, NGN and AGN}

Calibration curves for PHBA $(2.5-60.0 \mu \mathrm{g}$ $\left.\mathrm{ml}^{-1}\right)$, NGN (5.0-80.0 $\left.\mu \mathrm{g} \mathrm{ml}^{-1}\right)$ and AGN (5.0-80.0 $\mu \mathrm{g} \mathrm{ml}^{-1}$ ) were prepared by injecting the different concentrations of standard samples, recording their peak areas and plotting peak areas obtained vs. concentration.

\subsection{Precision, repeatability and accuracy}

Precision of the method was determined by intraday variation in the concentration of standard solutions of PHBA, NGN and AGN. Repeatability of the developed method was determined by six replicate injections repeated three times on the same day and additionally on two consecutive days at three different concentration levels (5.0, 20.0, and $40.0 \mu \mathrm{g} \mathrm{ml}^{-1}$ for PHBA; 10.0, 40.0, and 80.0 $\mu \mathrm{g} \mathrm{ml}^{-1}$ for NGN; 10.0, 40.0, and $80.0 \mu \mathrm{g} \mathrm{ml}^{-1}$ for AGN) to determine intraday and interday precisions. The repeatability of peak area is expressed in terms of relative standard deviation (RSD).

The accuracy of an analytical method is the closeness of test results obtained by the method to the true value and was determined based on the recovery of known amounts of analyte. Analytical recovery was performed by analyzing the analytes spiked with the three standards in mobile phase blank as well as in real extracts of $V$. negundo and $V$. trifolia. The recovery percentage was calculated by using the formula: recovery $(\%)=[($ amount found - original amount) / (spiked amount) $] \times 100$.

\subsection{Limit of detection (LOD) and limit of quantification (LOQ)}

The LOD was defined as the lowest amount of sample concentration that could be detected ( signal to noise ratio $=3.0$ ). The LOQ was defined as the lowest amount of sample concentration that could be quantitatively determined with suitable precision and accuracy (signal to noise ratio $=10.0$ ).

\subsection{Linearity and lack of fit test for linearity}

The linearity was measured by analyzing three standards at a minimum of six calibration points and for each point, two measurements were made. Calibration curves were constructed as a function of the concentrations of standard analytes $(x)$ vs. their peak area $(y)$. The lack of fit test is commonly used to ascertain whether the chosen regression model adequately fits the data, and was used to examine the linearity of the calibration curves for PHBA, NGN and AGN prepared using the developed HPLC method.

\subsection{Robustness}

To test the robustness of the HPLC method, chromatographic conditions that may affect the performance of the method, such as flow rate, organic content in mobile phase and wavelength of detection, were deliberately changed. One parameter was varied at a time, while the rest were kept constant. The effects on the results in terms of peak areas were examined. Also, the robustness of the developed HPLC method was verified on two other HPLC systems (Shimadzu Prominence UPLC and Shimadzu SPD $10 \mathrm{~A}$ ). Very low value (less than $5.0 \%$ ) of overall RSD (\%) between the data at each variable condition (flow rate, organic content in mobile phase and wavelength of detection) established the robustness of the developed HPLC method.

\subsection{System suitability and stability studies}

The HPLC method was also validated for its system suitability parameters, such as plate count, tailing factor, capacity factor, resolution, selectivity, purity angle and purity threshold values. For stability studies, standard samples of PHBA, NGN and AGN stored at $4{ }^{\circ} \mathrm{C}$ were analyzed at various time intervals for 3 weeks. The three analytes were stable in solution, and cumulative RSD (\%) of the area for all three analytes was below $5.0 \%$.

\subsection{Statistical analysis}

The statistical software SAS 9.2, SAS Institute Inc. [36] was used for the statistical analysis of response data of HPLC parameters. The responses were partitioned into various components of the simple linear regression model $Y_{\mathrm{i}}=\beta_{0}+\beta_{\mathrm{i}} X_{\mathrm{i}}+\varepsilon_{\mathrm{i}}$, where $\beta_{0}$ is the intercept, $\beta_{\mathrm{i}}$ is the slope, and $\varepsilon$ is the error. The proc reg procedure was used with replicate mean data of each treatment to determine the 
model parameters. The best fit of the model was determined by using the lack of fit test which compares the variation around the model with "pure" variation within replicated observations.

\section{RESULTS AND DISCUSSION}

In the Indian systems of medicine, the Vitex species are used for the treatment of a range of diseases. $V$. negundo and $V$. trifolia are the major plants among Vitex species [37]. Because of the increasing interest in herbal preparations from $\mathrm{Vi}$ tex species, their standardization is becoming increasingly important. Although, whole extracts of Vitex have been found to be bioactive in many bioassays, nevertheless, their standardization is desired for clinical studies, quality control of herbal preparations, and chemotaxonomic studies. PHBA, NGN and AGN are the three major bioactive compounds most suitable for these studies. Attempts were made to separate PHBA, NGN and AGN in a mixed standard using the reversed-phase $\mathrm{C}_{18}$ column with several elution systems. It was observed that the resolution of peaks was unsatisfactory when a mixture of acetonitrile and water or methanol and water was used as the mobile phase. Several modifiers, such as $O$-phosphoric acid, acetic acid, formic acid and TFA in the mobile phase were also used for optimization of chromatographic separation. Acetonitrile provided better resolution than methanol as the organic phase. Further, different percentages were tried and the organic phase (methanol/acetonitrile) percentage in the mobile phase was also optimized. The results suggested that the mobile phase composed of acetonitrile $(15.0 \%, \mathrm{~A})$ as the organic phase and $0.05 \%$ TFA in water $(85.0 \%, \mathrm{~B})$ in an isocratic elution mode with a flow rate of $1.0 \mathrm{ml} \mathrm{min}{ }^{-1}$ was suitable for chromatographic separation of PHBA, NGN and AGN in a mixture. Therefore, this mobile phase composition A : B $(15.0: 85.0, v / v)$ was selected for the method development. Under the optimized conditions, three standards were well resolved with relatively high sensitivity at a mean retention time $\left(t_{\mathrm{R}}\right)$ of $7.44,8.18$ and $14.86 \mathrm{~min}$ for PHBA, NGN and AGN, respectively, when absorption was measured at $258 \mathrm{~nm}$ (Table 1, Figure 2 ). At this wavelength, the best resolution between peaks, as well as baseline separation, was achieved and no interfering peaks were observed in the blank. The total run time was 25 min to ensure any late eluting peaks. The representative chromatograms of different extracts $\left(1 \mathrm{mg} \mathrm{ml}^{-1}\right)$ of $V$. $n e g u n d o$ and $V$. trifolia leaves and bark monitored at $258 \mathrm{~nm}$ are shown in Figures 3 and 4.

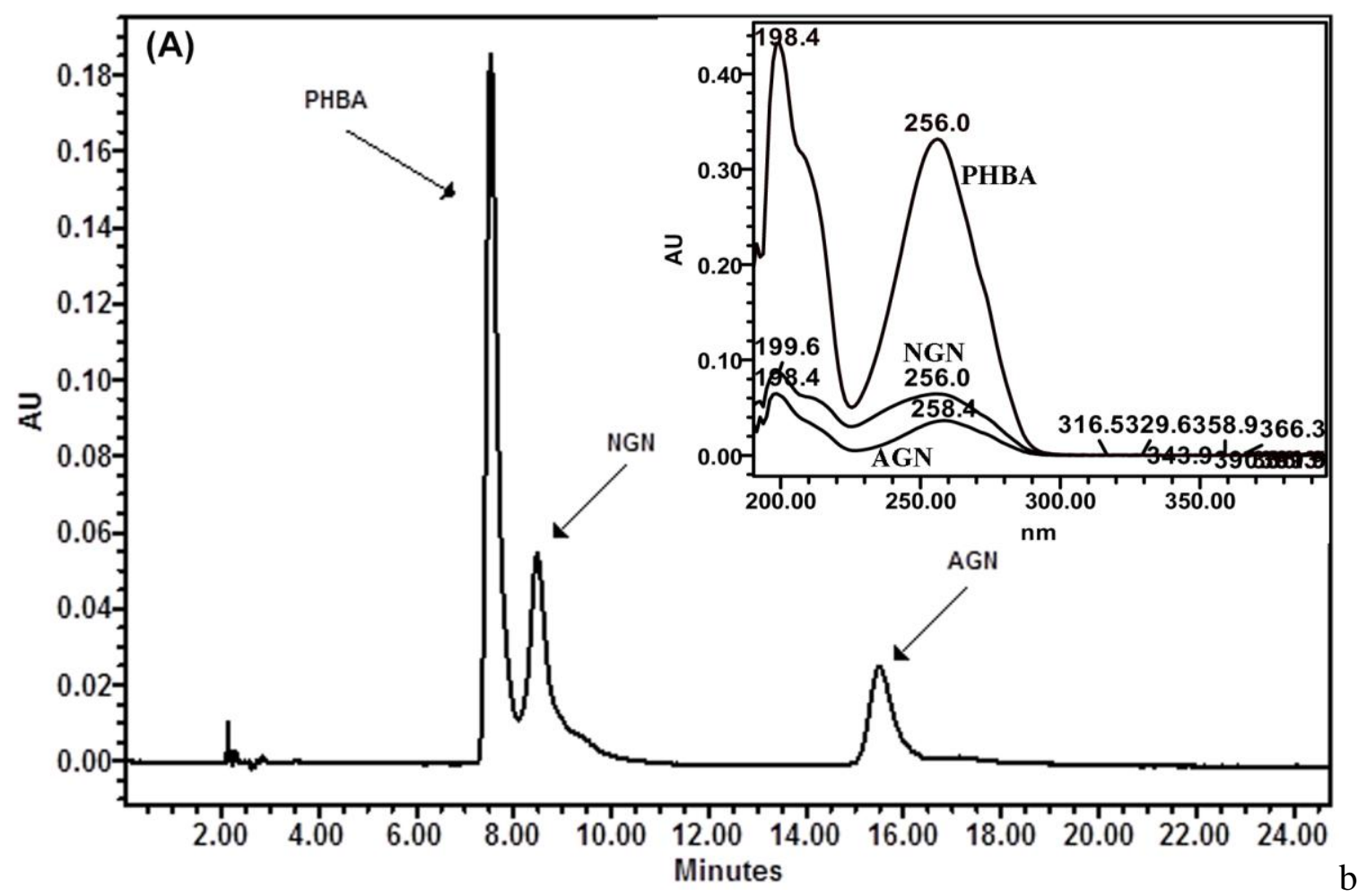

Fig. 2. HPLC chromatogram of a standard mixture of PHBA, NGN and AGN $\left(20.0 \mu \mathrm{g} \mathrm{ml}^{-1}\right)$ and their corresponding UV spectra 
Table 1

Linear relationship between peak area and concentration of PHBA, NGN and AGN

\begin{tabular}{|c|c|c|c|c|c|c|c|}
\hline \multirow[t]{2}{*}{ Analyte } & \multicolumn{2}{|c|}{$\begin{array}{l}\text { Retention time }\left(t_{\mathrm{R}}\right) \\
\min \end{array}$} & \multirow{2}{*}{$\begin{array}{l}\text { Regression equation } \\
\qquad(y=a x+b)\end{array}$} & \multirow[t]{2}{*}{$r^{2}$} & \multirow{2}{*}{$\begin{array}{l}\text { Linear range } \\
\left.(\mu \mathrm{g} \mathrm{ml})^{-1}\right)\end{array}$} & \multirow{2}{*}{$\begin{array}{c}\text { LOD } \\
\left(\mu \mathrm{g} \mathrm{ml}^{-1}\right)\end{array}$} & \multirow{2}{*}{$\begin{array}{c}\text { LOQ } \\
\left(\mu \mathrm{g} \mathrm{ml}^{-1}\right)\end{array}$} \\
\hline & Mean & RSD (\%) & & & & & \\
\hline PHBA & 7.44 & 0.15 & $y=131107 x-27226$ & 0.999 & $2.5-60.0$ & 1.00 & 2.50 \\
\hline NGN & 8.18 & 0.39 & $y=22872 x+22920$ & 0.997 & $5.0-80.0$ & 2.50 & 5.00 \\
\hline AGN & 14.86 & 0.92 & $y=27150 x-24999$ & 0.998 & $5.0-80.0$ & 2.50 & 5.00 \\
\hline
\end{tabular}
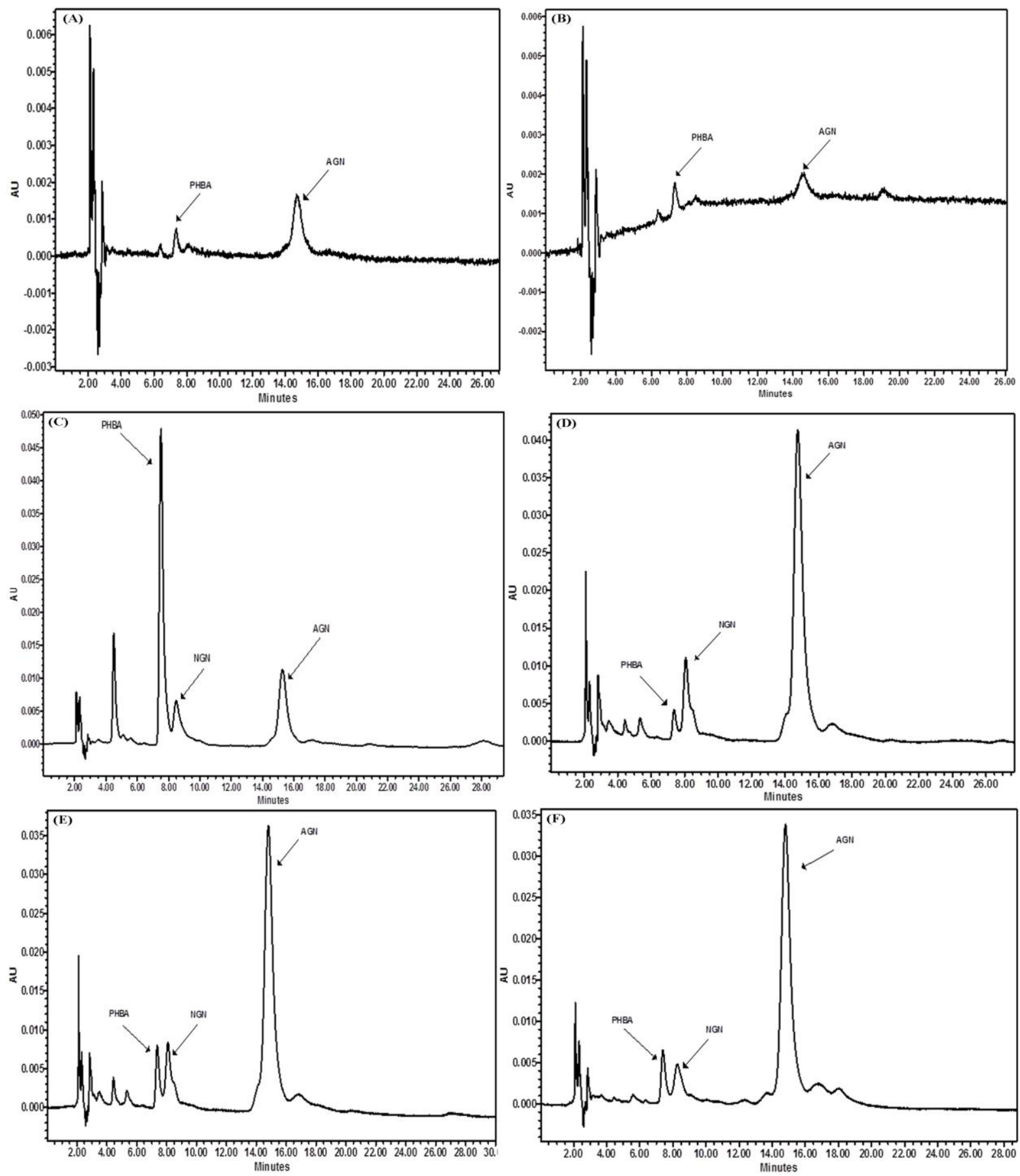

Fig. 3. HPLC chromatograms (1000.0 $\mu \mathrm{g} \mathrm{ml}^{-1}$ ) of hexane extract (A), chloroform extract (B), ethyl acetate extract (C), aqueous extract (D), methanol extract (E) of $V$. negundo leaves, and methanol extract (F) of $V$. negundo bark 

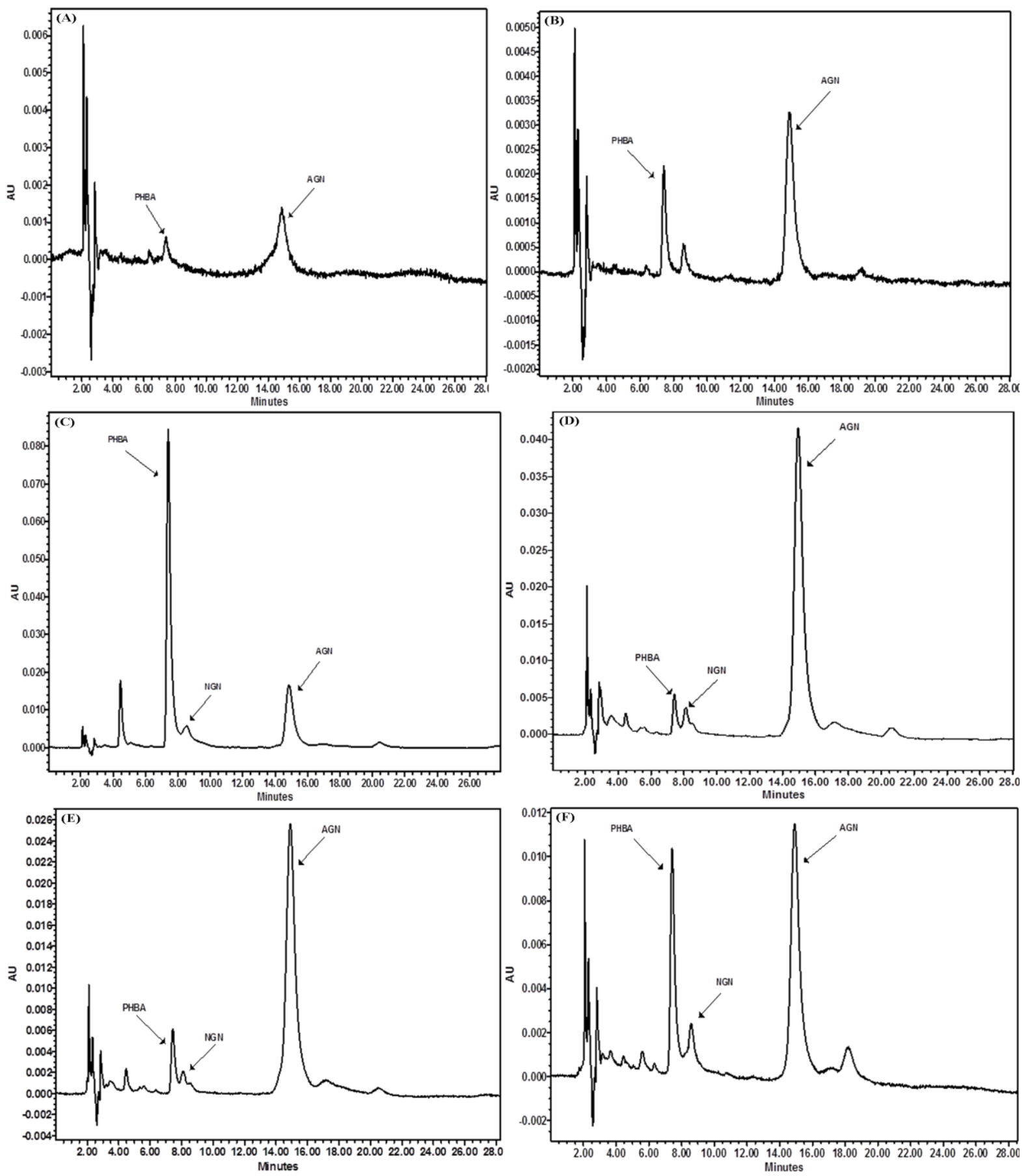

Fig. 4. HPLC chromatograms $\left(1000.0 \mu \mathrm{g} \mathrm{ml}^{-1}\right)$ of hexane extract (A), chloroform extract (B), ethyl acetate extract (C), aqueous extract (D), methanol extract (E) of $V$. trifolia leaves, and methanol extract (F) of $V$. trifolia bark

To ensure the accurate assessment of PHBA, NGN and AGN in Vitex extracts, the developed HPLC method was validated according to the ICH guidelines on the validation of analytical methods [38]. The LOD was found to be 1.00, 2.50 and 2.50 $\mu \mathrm{g} \mathrm{ml}{ }^{-1}$ for PHBA, NGN and AGN, respectively, which indicated high sensitivity under the applied HPLC conditions. The LOQ was found to be 2.50, 5.00 and $5.00 \mu \mathrm{g} \mathrm{ml}^{-1}$ for PHBA, NGN and AGN, respectively. Calibration curves were linear over a large concentration range: $2.5-60.0,5.0-80.0$, and
5.0-80.0 $\mu \mathrm{g} \mathrm{m}^{-1}$ for PHBA, NGN and AGN, respectively (Table 1). The lack of fit test confirmed the adequacy of the linear model (Table 2). The results of the intraday and interday precision experiments are shown in Table 3. The developed method was found to be precise, as the RSD values for repeatability of intraday and inter day precision studies were less than $5.0 \%$, which is under the limit recommended by the ICH guidelines (Table 3). These results established that the developed method was reproducible with good accuracy. Fur- 
ther, chromatograms indicated that the method was specific for determination of PHBA, NGN and AGN under chromatographic conditions since peak purity showed that peaks are pure and had no co- eluting peaks. Also, no interferences were observed in blank as no peak was observed at the retention time $\left(t_{\mathrm{R}}\right)$ of PHBA, NGN and AGN, thereby, demonstrating the specificity of the method.

Table 2

Lack of fit test for calibration curves of PHBA, NGN and AGN

\begin{tabular}{ccccccc}
\hline Analyte & Residual & DF* & Sum of squares & Mean square & F Value & Pr $>$ F \\
\hline \multirow{3}{*}{ PHBA } & Lack of fit & 4 & 10.589428 & 2.647357 & & \\
& Pure error & 30 & 7.932127 & 0.264404 & 10.01 & $<0.0001$ \\
& Total error & 34 & 18.521555 & 0.544752 & & \\
\hline \multirow{3}{*}{ NGN } & Lack of fit & 4 & 4.555998 & 1.139000 & & \\
& Pure error & 30 & 2.009549 & 0.066985 & 17.00 & $<0.0001$ \\
& Total error & 34 & 6.565547 & 0.193104 & & \\
\hline \multirow{3}{*}{ AGN } & Lack of fit & 4 & 124.680031 & 31.170008 & & $<0.0001$ \\
& Pure error & 30 & 2.226620 & 0.074221 & 419.96 & \\
\hline \hline
\end{tabular}

$* \mathrm{DF}=$ degrees of freedom

Table 3

Intraday and interday precision (RSD \%)

\begin{tabular}{ccccc}
\hline Analyte & $\begin{array}{c}\text { Concentration } \\
\left(\mu \mathrm{g} \mathrm{ml}^{-1}\right)\end{array}$ & $\begin{array}{c}\text { Intra- } \\
\text { day }\end{array}$ & $\begin{array}{c}\text { Inter- } \\
\text { day }\end{array}$ & $\begin{array}{c}\text { Recovery } \\
(\%)\end{array}$ \\
\hline \multirow{3}{*}{ PHBA } & 5.0 & 1.60 & 0.69 & 102 \\
& 20.0 & 1.10 & 0.41 & 101 \\
& 40.0 & 0.76 & 2.40 & 99 \\
\hline \multirow{3}{*}{ NGN } & 10.0 & 4.58 & 0.07 & 97 \\
& 40.0 & 1.15 & 0.37 & 102 \\
& 80.0 & 1.44 & 3.28 & 102 \\
\hline \multirow{3}{*}{ AGN } & 10.0 & 1.93 & 1.32 & 100 \\
& 40.0 & 0.86 & 3.23 & 99 \\
\hline \hline
\end{tabular}

$n=3$

Table 4

System suitability and peak purity parameters for PHBA, NGN, and AGN

\begin{tabular}{lrrr}
\hline \multicolumn{1}{c}{ Parameter } & PHBA & NGN & AGN \\
\hline USP plate count & 3847 & 4654 & 3912 \\
USP tailing & 0.70 & 0.93 & 0.90 \\
Capacity factor & 5.55 & 6.32 & 12.09 \\
Resolution & - & 1.85 & 8.74 \\
Selectivity & 1.39 & 1.15 & 1.91 \\
Purity angle & 0.022 & 0.160 & 0.209 \\
Purity threshold & 0.244 & 0.208 & 0.356 \\
\hline \hline
\end{tabular}

Recovery studies were carried out to check the accuracy of the developed HPLC method. Three different quantities (low, medium and high) of the standards were spiked into blank samples.
The spiked samples were quantified in accordance with the methods mentioned above. The overall recovery percentages of PHBA, NGN and AGN were in the range $97-102 \%$ (Table 3). These results demonstrated that the developed method was reproducible with good accuracy. System suitability parameters for PHBA, NGN and AGN demonstrated that the method is suitable for determining these three compounds in Vitex extracts (Table 4).

The extraction yields of $V$. negundo and $V$. trifolia leaves prepared using different solvents are shown in Figure 5. The developed HPLC method was applied for the determination of PHBA, NGN and AGN contents in the different extracts (Figures 3 and 4) of the leaves and bark of $V$. negundo and $V$. trifolia. The contents of PHBA, NGN and AGN in different extracts are summarized in Table 5. PHBA was detected in all extracts of $V$. negundo and $V$. trifolia and ranged from $0.13 \pm 0.11 \%$ to $2.55 \pm 0.14 \%$ in $V$. negundo extracts, and $0.12 \pm 0.09 \%$ to $4.23 \pm 0.08 \%$ in $V$. trifolia extracts. Ethyl acetate extract had the highest concentration of PHBA followed by methanol and aqueous extract. NGN was not detected in hexane and chloroform extracts of $V$. negundo and $V$. trifolia leaves. Extracts prepared from leaves of $V$. trifolia had lower concentration of NGN than the corresponding extracts of $V$. negundo leaves. It ranged from $1.55 \pm 0.06 \%$ to $2.17 \pm 0.05 \%$ in $V$. negundo leaf extract. Similarly, it varied from $0.21 \pm 0.06 \%$ to $0.72 \pm 0.10 \%$ in $V$. trifolia leaf extract. Roy et al. [30] also reported NGN content $(w / w)$ in $V$. negundo leaves collected from three different re- 
gions of India in the range $0.32 \pm 0.003 \%$ to $0.76+0.008 \%$. NGN was also detected in methanol extract of $V$. negundo and $V$. trifolia bark samples. Its concentration was higher in $V$. negundo bark extract. AGN was detected in all six extracts of $V$. negundo and $V$. trifolia leaves. In comparison with other extracts, aqueous extracts of leaves had the highest concentration of AGN, followed by methanol and ethyl acetate extracts. This may justify the use of aqueous extract of fresh mature leaves of $V$. negundo in Ayurvedic medicine as anti inflammatory, analgesic and anti-itching agents, both internally and externally [24]. AGN content as reported by Roy et al [30] varied in the range $0.54 \pm 0.01 \%$ to $2.20 \pm 0.01 \%$.

Bark methanol extracts had lower concentration of AGN than the corresponding leaf extracts. Similar results were reported by Tiwari et al. [35].
Contents of PHBA, NGN and AGN were lower in bark samples than in leaf samples, and therefore, leaf needs to be used so that Vitex species can be better protected and utilized.

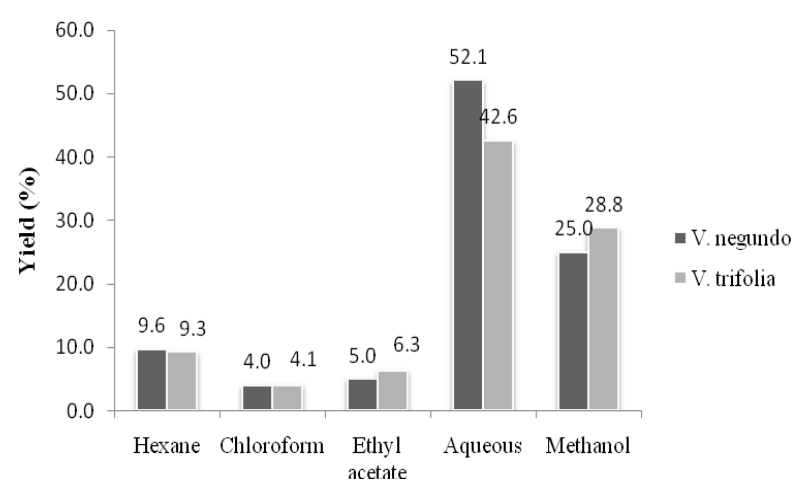

Fig 5. Extract yield of V. negundo and V.trifolia leaves prepared using different solvents

Table 5

Applicability of the developed HPLC method for the determination of concentrations of PHBA, NGN and $A G N$ in $V$. negundo and $V$. trifolia extracts

\begin{tabular}{|c|c|c|c|}
\hline & $\begin{array}{c}\text { PHBA } \\
\left(\text { mean } \pm \text { S.D., } \%^{*}\right)\end{array}$ & $\begin{array}{c}\text { NGN } \\
\left(\text { mean } \pm \text { S.D., } \%^{*}\right)\end{array}$ & $\begin{array}{c}\text { AGN } \\
\left(\text { mean } \pm \text { S.D., \% }{ }^{*}\right)\end{array}$ \\
\hline $\begin{array}{l}\text { V. negundo leaves } \\
\text { Hexane }\end{array}$ & $0.13 \pm 0.11$ & ND & $1.53 \pm 0.07$ \\
\hline Chloroform & $0.14 \pm 0.07$ & ND & $0.77 \pm 0.06$ \\
\hline Ethyl acetate & $2.55 \pm 0.14$ & $1.74 \pm 0.09$ & $5.77 \pm 0.05$ \\
\hline Aqueous & $0.22 \pm 0.07$ & $2.17 \pm 0.05$ & $20.85 \pm 0.13$ \\
\hline Methanol & $0.43 \pm 0.08$ & $1.55 \pm 0.06$ & $19.56 \pm 0.05$ \\
\hline \multicolumn{4}{|l|}{ V. negundo bark } \\
\hline Methanol & $0.39 \pm 0.05$ & $1.35 \pm 0.0$ & $19.34 \pm 0.08$ \\
\hline \multicolumn{4}{|l|}{ V. trifolia leaves } \\
\hline Hexane & $0.12 \pm 0.09$ & ND & $1.45 \pm 0.07$ \\
\hline Chloroform & $0.19 \pm 0.06$ & ND & $2.27 \pm 0.04$ \\
\hline Ethyl acetate & $4.23 \pm 0.08$ & $0.72 \pm 0.10$ & $8.49 \pm 0.06$ \\
\hline Aqueous & $0.29 \pm 0.11$ & $0.27 \pm 0.05$ & $22.53 \pm 0.07$ \\
\hline Methanol & $0.57 \pm 0.05$ & $0.21 \pm 0.06$ & $23.10 \pm 0.08$ \\
\hline \multicolumn{4}{|l|}{ V. trifolia bark } \\
\hline Methanol & $0.62 \pm 0.07$ & $0.34 \pm 0.12$ & $6.87 \pm 0.06$ \\
\hline
\end{tabular}

$*_{n}=6, \mathrm{ND}=$ not detected

\section{CONCLUSION}

A simple and efficient reversed-phase HPLC method was developed for simultaneous identification and quantification of PHBA, NGN and AGN in different extracts prepared from leaves and bark of $V$. negundo and $V$. trifolia. The developed HPLC method is simple, precise and accurate. Further, it was also validated as per ICH guidelines. The developed HPLC method has the following merits: firstly, three compounds PHBA, NGN and AGN can be analyzed simultaneously without any tedious sample preparation; secondly, the analysis is rapid, and therefore, suitable for quantitative analysis, as well as quality control of extracts and herbal formulations from Vitex species; thirdly, sample preparation does not require use of solid phase extraction to optimize the separation of PHBA, NGN and AGN from other polyphenolic compounds present in the extract samples. Further, on the basis of the above results, selection of a suitable solvent can be made for the up-scaling of individual compounds.

The developed method can be used for bioprospecting for other Vitex species available in India, as well as quality control of herbal formulations con- 
taining the above three molecules, and also for pharmacokinetic studies of related extracts and drug.

Acknowledgements. Authors express their sincere thanks to the Director, DMAPR, Anand for permitting the research work. We also acknowledge the help rendered by Dr. R. Nagaraja Reddy, Scientist (Plant Breeding) for statistical analysis and Shri B. K. Mishra, Technical Assistant, for laboratory assistance.

\section{REFERENCES}

[1] P. K. Dutta, U. S. Chowdhury, A. K. Chkravarty, B. Achari, S. C. Pakrashi, Studies on Indian medicinal plants - part LXXV. Nishindaside, a novel iridoid glycoside from Vitex negundo, Tetrahed., 39, 3067-3072 (1983).

[2] T. A. Iwagawa, A. Nakahara, M. Nakatani, Iridoids from Vitex cannabifolia, Phytochem., 32, 453-454 (1993).

[3] I. Kouno, M. Inoue, Y. Onizuka, T. Fujisaki, N. Kawano, Iridoid and phenolic glucoside from Vitex rotundifolia, Phytochem., 27, 611-612 (1998).

[4] E. Okuyama, S. Fujimori, M. Yamazaki, T. Deyama, Pharmacologically active components of Viticis fructus (Vitex rotundifolia). II. The components having analgesic effects, Chem Pharm Bull., 46, 655-662 (1998).

[5] M. Ono, Y. Ito, S. Kubo, T. Nohara, Two new iridoids from Viticis trifoliae fructus (fruits of Vitex rotundifolia L.), Chem Pharm Bull., 45, 1094-1096 (1997).

[6] H. Rimpler, Iridoids and ecdysones from Vitex species, Phytochem., 11, 2652-2653 (1972).

[7] T. C. Santos, J. Schripsema, F. D. Monache, S. G. Leitao, Iridoids from Vitex cymosa, J Brazilian Chem Soc., 12, 763-766 (2011).

[8] C. K. Sehgal, S. C. Taneja, K. L. Dhar, C. K. Atal, 2'-pHydroxybenzoyl mussaenosidic acid, a new iridoid glucoside from Vitex negundo, Phytochem., 21, 363-366 (1982).

[9] C. K. Sehgal, S. C. Taneja, K. L. Dhar, C. K. Atal, 6'-pHydroxybenzoyl mussaenosidic acid - an iridoid glucoside from Vitex negundo, Phytochem., 22, 1036-1038 (1983).

[10] A. Suksamrarn, S. Kumpun, K. Kirtikara, B. Yingyongnarongkul, S. Suksamrarn, Iridoids from $\mathrm{Vi}$ tex peduncularis, Planta Med., 68, 72-73 (2002).

[11] R. K. Gupta, V. R. Tondon, Antinociceptive activity of Vitex negundo Linn leaf extract, Indian $J$ Physiol Pharmacol., 49, 163-170 (2005).

[12] V. R. Tondon, R. K. Gupta, Anti-inflammatory activity and mechanism of action of Vitex negundo Linn, Int $J$ Pharmacol., 2, 303-308 (2006).

[13] V. R. Tondon, R. K. Gupta, An experimental evaluation of anticonvulsant activity of Vitex negundo, Indian $J$ Physiol Pharmacol., 49, 199-205 (2005).

[14] V. R. Tondon, R. K. Gupta, Effect of Vitex negundo on oxidative stress, Indian J Pharmacol, 37, 38-40 (2005).

[15] M. Kumar, P. Rawat, P. Dixit, D. Mishra, A. K. Gautam, R. Pandey, R. Singh, N. Chattopadhyay, R. Maurya, Anti-osteoporotic constituents from Indian medicinal plants, Phytomed., 17, 993-999 (2010).
[16] M. Ikram., S. G. Khattak, S. N. Gilani, Antipyretic studies on some indigenous Pakistani medicinal plants: II., $J$. Ethnopharmacol., 19, 185-187 (1987).

[17] M. M. Hossain, N. Paul, N. H. Sohrab, E. Rahman, M. A. Rashid, Antimicrobial activity of Vitex trifolia, Fitoter., 72, 695-697 (2001).

[18] Z. Ikwati, S. Wahyuono, K. Maeyama, Screening of several Indonesian medicinal plants for their inhibitory effect on histamine release from RBL-2H3 cells, $J$. Ethnopharmacol., 75, 249-256 (2001).

[19] R. N. Chopra, S. L. Nayar, I. C. Chopra, In: Glossary of Indian Medicinal Plants, CSIR Publications, New Delhi. 1956, pp. 257

[20] S. A. Tasduq, P. J. Kaiser, B. D. Gupta, V. K. Gupta, R. K. Johri, Negundoside, an irridiod glycoside from leaves of Vitex negundo protects human liver cells against calcium-mediated toxicity induced by carbon tetrachloride, World J Gastroent., 14, 3693-3709 (2008).

[21] R. L. Sharma, A. Prabhakar, K. L. Dhar, A. A. Sachar, A new iridoid glycoside from Vitex negundo Linn (Verbenacea), Nat Prod Res., 23, 1201-1209 (2009).

[22] R. Hansel, C. H. Leukert, H. Rimpler, K. D. Schaaf, Chemotaxonomische Untersuchungen in der Gattung Vitex L., Phytochem., 4, 19-27 (1995).

[23] E. Hoberg, B. Meier, O. Sticher, An analytical high performance liquid chromatographic method for the determination of agnuside and $p$-hydroxybenzoic acid contents in agni-casti fructus, Phytochem Anal., 11, 327329 (2000).

[24] A. Pandey, S. Bani, N. K. Satti, B. D. Gupta, K. A. Suri, Anti-arthritic activity of agnuside mediated through the down regulation of inflammatory mediators and cytokines, Inflamm Res., 61, 293-304 (2012).

[25] F. M. Natella, M. Nardini, Di. Felice, C. Scaccini, Benzoic and cinnamic acid derivatives as antioxidants: structure activity relation, J Agric and Food Chem., 47, 1453-1459 (1997).

[26] D. Pugazhendhi, G. S. Pope, P. D. Darbre, Oestrogenic activity of $p$-hydroxy benzoic acid (common metabolite of paraben esters) and methyl paraben in human breast cell lines, J Appl Toxicol., 25, 301-309 (2005).

[27] S. M. Panicker, Estimation of agnuside, negundoside and 1,4,dihydroxy benzoic acid from Vitex negundo Linn. by HPLC. M. Pharm Dissertation submitted to Rajiv Gandhi University of Health Sciences, Bangalore, India (2010).

[28] A. P. Sing, S. Ryali, P. Varadhacharyulu, Negundoside from leaves of Vitex negundo, Int J Chem \& Anal Sci., 2, 1197-1198 (2011).

[29] P. J. Lokhande, J. K. Verma, Quantification of negundoside in Vitex negundo Linn. leaf powder by high-performance liquid chromatography, Acta Chromatgr., 22, 591-597 (2010).

[30] S. K. Roy, K. Bairwa, J. Grover, A. Srivastava, S. M. Jachak, Analysis of flavonoids and Iridoids in Vitex negundo by HPLC-PDA and method validation, Nat Prod Commun., 8, 1241-1244 (2013).

[31] S. Shah, T. Dhanani. S.Kumar, Validated HPLC method for identification and quantification of p-hydroxy benzo- 
ic acid and agnuside in Vitex negundo and Vitex trifolia. J Pharm Anal., 3, 500-508 (2013).

[32] C. Hogner, S. Sturm, C. Seger, H. Stuppner, Development and validation of a rapid ultra-high performance liquid chromatography diode array detector method for Vitex agnus-castus, J Chromatogr. B, 927, 181-190 (2013).

[33] P. J. Lokhande, J. K. Verma, Quantification of negundoside in Vitex negundo Linn. leaf by high performance thin-layer chromatography, $J$ Planar Chromatgr., 22, 225-228 (2009).

[34] N. Tiwari, D. Yadav, S. C.Singh, M. M.Gupta, A marker based stability indicating high performance thin layer chromatographic method for Vitex trifolia, J Liq Chromatogr Rel Technol., 34, 1925-1937 (2011).
[35] N. Tiwari, S. Luqman, N. Masood, M. M.Gupta, Validated high performance thin layer chromatographic method for simultaneous quantification of major iridoids in Vitex trifolia and their antioxidant studies, $J$ Pharm and Biomed Anal., 61, 207-214 (2012).

[36] SAS/STATR 10179.2 User's guide, Cary: SAS Institute Inc. 2008.

[37] K. A. Kannathasan, M. Senthilkumar, Chandrasekaran, V. Venkatesalu, Differential larvicidal efficacy of four species of Vitex against Culex quinquefasciatus larvae, Parasitol Res., 101, 1721-1723 (2007).

[38] International Conference on Harmonization. ICH Q2 (R1); Validation of Analytical Procedures: Text Methodology, Geneva, 2000. 